\title{
The Structure of Cemento-dentinal Junction in Mandibular Deciduous Second Molars and Permanent First Molars in Egyptian Populations (Scanning Electron Microscope Study)
}

Original Article

\author{
Raneem F. Obeid and Radwa T. El-Sharkawy
}

Department of Oral Biology, Faculty of Oral and Dental Medicine, Future University in Egypt, Cairo, Egypt

\begin{abstract}
Introduction: Cementodentinal junction (CDJ) is the interface between cementum and dentin. The cause of this attachment was described by the intermingling of cemental and dentinal fibers or the accumulation of adhesive proteoglycans at the cementodentinal junction. Cementum was classified to three major types according to the type of fibers; Acellular extrinsic fiber cementum, Cellular intrinsic fiber cementum and Cellular mixed stratified cementum.

Aim of Work: To observe the cemento-dentinal junction in human mandibular deciduous $2^{\text {nd }}$ molar and mandibular permanent $1^{\text {st }}$ molar by scanning electron microscopy combined by $\mathrm{NaOH}$ maceration.

Materials and Methods: Twenty extracted mandibular deciduous $2^{\text {nd }}$ molar and mandibular permanent $1^{\text {st }}$ molar with complete $\operatorname{root}(\mathrm{s})$, were collected. The teeth preserved in $10 \%$ formalin then divided into two groups consisted of 10 teeth each. All teeth were cut mesiodistally into halves with a diamond desk, then the sectioned halves were demineralized by formic acid $10 \%$ for one month then were immersed in $10 \% \mathrm{NaOH}$ aqueous solution for 2-3 days at room temperature and rinsed in distilled water overnight (24 hours).

Results: Acellular cementum in mandibular deciduous $2^{\text {nd }}$ molars showed a gap with complete separation, while in cellular cementum there is fibril poor gap and fibril intermingling between the intrinsic fibers of cellular cementum and dentin root fibers. The gap and the intermingling fibers were not observed in the examination of cellular cementum in mandibular permanent $1^{\text {st }}$ molars while in acellular cementum there is a fiber intermingling observed.

Conclusion: Fibril intermingling plays a role in cementum to dentin attachment.
\end{abstract}

Received: 09 August 2020, Accepted: 01 September 2020

Key Words: Cementodentinal junction, deciduous molar, fiber intermingling, $\mathrm{NaOH}$ maceration, permanent molar.

Corresponding Author: Raneem Farouk Obeid, PhD, Department of Oral Biology, Faculty of Oral and Dental Medicine, Future University, Cairo, Egypt, Tel.: +20 1006168513, E-mail: raneemobeid2@gmail.com - ranim.farouk@fue.edu.eg

ISSN: $1110-0559$, Vol. 44, No.3

\section{INTRODUCTION}

Cementodentinal junction (CDJ) is defined as the zone at the interface between cementum and dentin. The cause of the cementodentinal attachment was described by 2 different hypotheses, the first was the intermingling of cemental and dentinal fibers which creates firm attachment through mineralization, the second one is due to accumulation of adhesive proteoglycans at the cementodentinal junction which assumed to be more important than the fibril intermingling ${ }^{[1]}$.

Cementum is an essential mineralized dental tissue and is a part of the attachment apparatus within the periodontium, it is considered the medium for the attachment of the principal collagen fibers of the periodontal ligament thus attaching the tooth to the alveolar bone $\mathrm{e}^{[2,3]}$.

Cementum was classified according to the absence or presence of cells in the mineralized cementum matrix, two types of cementum are well known: acellular cementum covering the coronal two-third of the root and cellular cementum covering the apical third. Layers of cellular and acellular cementum may alternate ${ }^{[4]}$.
Also, according to the type of fibers cementum was classified to three major types;(1) Acellular extrinsic fiber cementum (AEFC) contains tightly packed extrinsic fibers and no cementocytes ${ }^{[2]}$. Cellular intrinsic fiber cementum (CIFC) contains intrinsic fibers and cementocytes ${ }^{[3]}$. Cellular mixed stratified cementum (CMSC) contains both extrinsic and intrinsic fibers and cementocytes ${ }^{[5,6]}$.

The surface of the dentin upon which the cementum is deposited is normally smooth in permanent teeth, however the cemento-dentinal junction, in deciduous teeth appeared scalloped. The attachment of the cementum to the dentin, in either case, is quite firm despite the nature of this attachment ${ }^{[7,8]}$.

The aim of this study was to observe the cementodentinal junction in human mandibular deciduous $2^{\text {nd }}$ molar and permanent $1^{\text {st }}$ molar by scanning electron microscopy combined by $\mathrm{NaOH}$ maceration.

\section{MATERIALS AND METHODS}

\section{Teeth preparation}

Twenty extracted mandibular deciduous $2^{\text {nd }}$ molar and permanent $1^{\text {st }}$ molar with complete $\operatorname{root}(\mathrm{s})$, were collected 
from pedodontics and surgical departments from the authors universities.

The teeth had been preserved in 10\% formalin then they were divided into two groups consisted of 10 teeth each.

All teeth were cut mesio-distally into halves with diamond desk, then the sectioned halves of each group were demineralized by formic acid $10 \%$ for one month $^{[1,6]}$. After demineralization, specimens were immersed in $10 \%$ $\mathrm{NaOH}$ aqueous solution for 2-3 days at room temperature and rinsed in distilled water overnight (24 hours) ${ }^{[9]} . \mathrm{NaOH}$ maceration is said to remove interfibrillar substances without damaging collagen.

\section{Scanning Electron Microscope}

Samples were examined by scanning electron microscope (SEM). SEM evaluation was done at the 'THE EGYPTIAN MINERAL RESOURCES AUTHORITY', Central Laboratories Sector. Using SEM Model Quanta 250 FEG (Field Emission Gun) attached with EDX Unit (Energy Dispersive X-ray Analyses), with accelerating voltage $30 \mathrm{~K} . \mathrm{V}$., magnification $14 \mathrm{x}$ up to 1000000 and resolution for Gun.1n). FEI company, Netherlands.

\section{Statistical analysis}

Statistical analysis was performed via Microsoft excel statistical analyzer, AVERAGE, STDEV.P and $P$ value calculated by $\mathrm{T}$ test to compare variables between the two groups. The results were considered statistically significant if the $p$ value was $\leq 0.05$.

\section{RESULTS}

\section{Scanning Electron Microscope}

By the examination with the SEM of acellular cementum in mandibular deciduous $2^{\text {nd }}$ molars showed gap with complete separation between acellular cementum and root dentin after $\mathrm{NAOH}$ maceration, the intermingling between intrinsic fibers of acellular cementum and dentinal fibrils at the cementodentinal junction was not observed (Figure 1).

In cellular cementum, the cementodentinal junction is fibril poor gap; fibril intermingling between the intrinsic fibers of cellular cementum and dentin root fibers (Figure 2). The fibers bundle of cellular cementum showed unorganized distribution (Figure 3).

In the examination of acellular cementum in mandibular permanent $1^{\text {st }}$ molars, they revealed poor gap between the acellular cementum and root dentin in some areas. While other areas, there were fibers intermingling between the internal fibers of acellular cementum and root dentin fibers (Figure 4).

The gap and the intermingling fibers were not observed in the examination of cellular cementum in mandibular permanent molars (Figure 5).

\section{Statistical analysis}

Regarding the gap between the cellular cementum and root dentin in mandibular deciduous $2^{\text {nd }}$ molar the average range was $5.9 \mu \mathrm{m}$ while in the acellular cementum the average range was $9.43 \mu \mathrm{m}$ and the $p$-value showed 1.013 which statistically not significant. In mandibular permanent $1^{\text {st }}$ molar, the average range of the gap between acellular cementum was $3.46 \mu \mathrm{m}$. (Table 1, Figure 6)

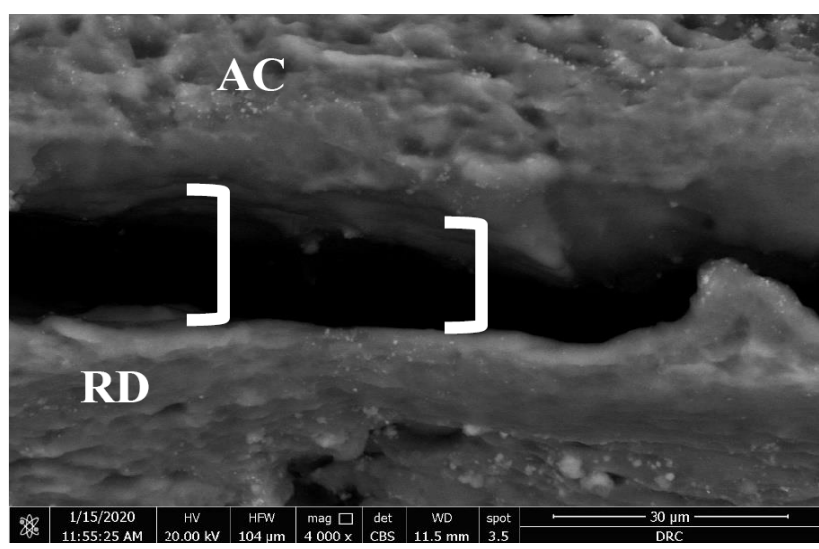

Fig. 1: Scanning electron micrograph of mandibular deciduous $2^{\text {nd }}$ molars showing gap ( ] ) with complete separation between acellular cementum (AC) and root dentin (RD) after NAOH maceration $\mathrm{x} 4000$

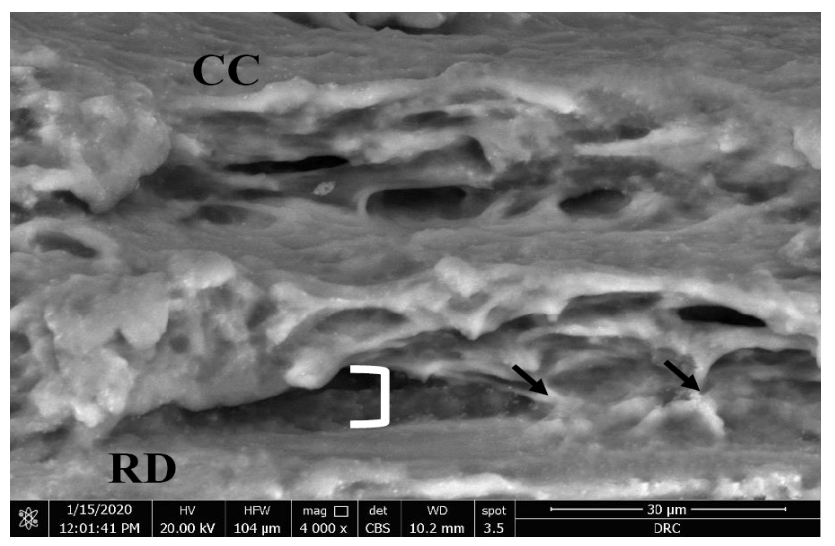

Fig. 2: Scanning electron micrograph of mandibular deciduous $2^{\text {nd }}$ molars showing fibril poor gap in cellular cementum (CC) (]) and fibril intermingling between the intrinsic fibers of cellular cementum (CC) and root dentin (RD) fibers (arrows) x 4000

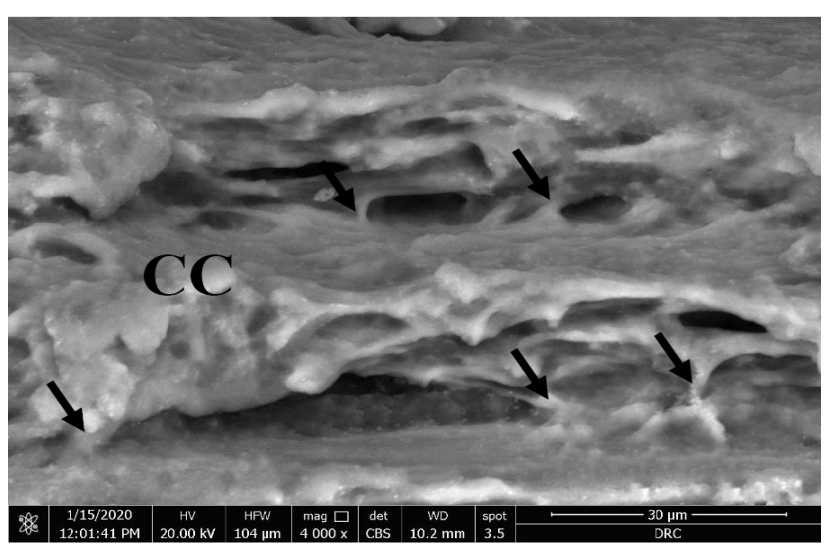

Fig. 3: Scanning electron micrograph of mandibular deciduous $2^{\text {nd }}$ molars in inner surface of cellular cementum (CC) showed the protruded fibers bundles (arrows) with unorganized distribution . X4000 


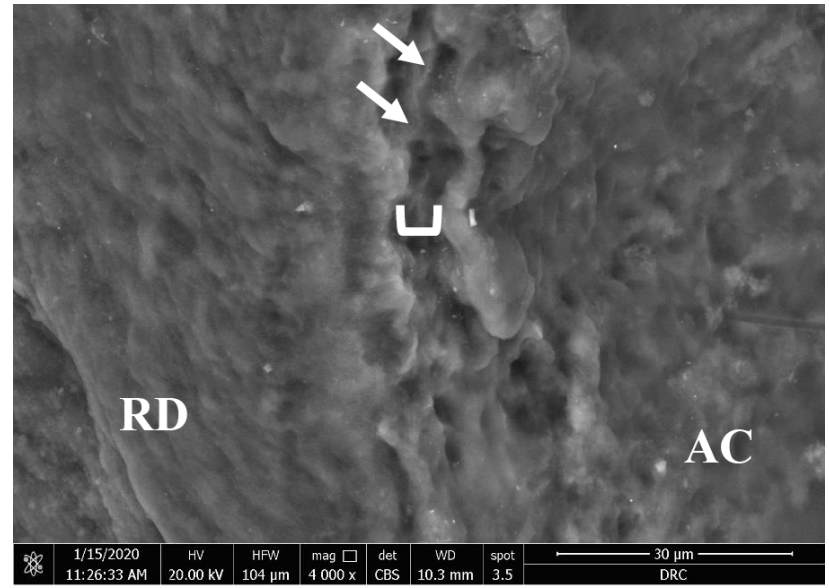

Fig. 4: Scanning electron micrograph of acellular cementum in mandibular permanent $1^{\text {st }}$ molars showed poor gap (]) with fibers intermingling between internal fibers of acellular cementum (AC) and root dentin (RD) fibers (arrows) x 4000.

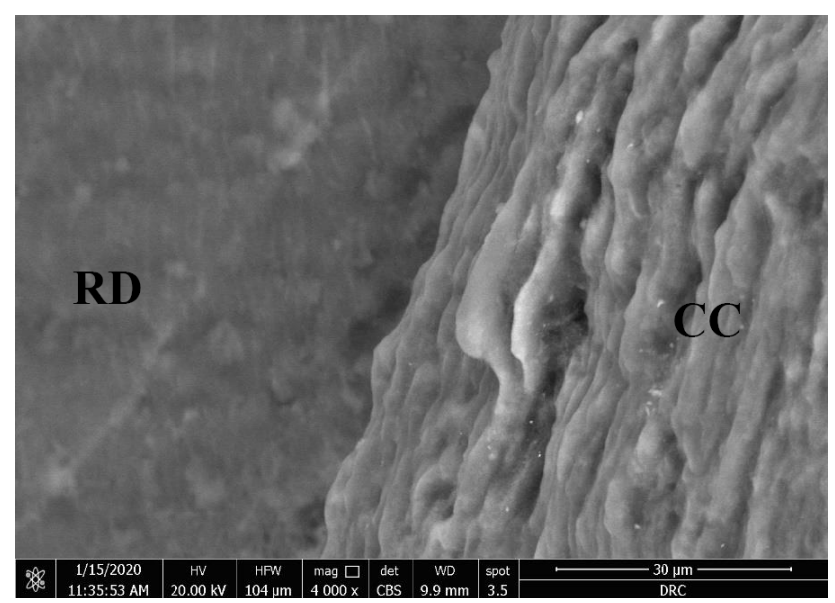

Fig. 5: Scanning electron micrograph of cellular cementum in permanent lower molars showed no gap or fibers intermingling between internal fibers of cellular cementum (CC) and root dentin (RD) fibers. x 4000.

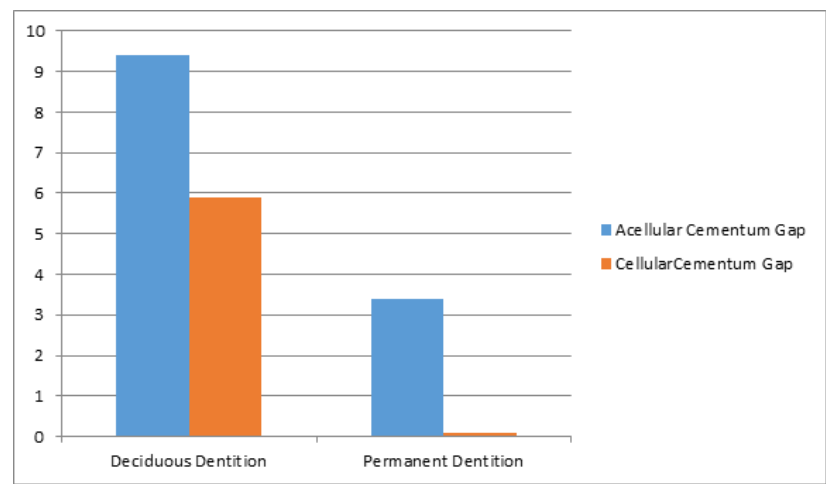

Fig. 6: Chart showing the average distance of gap in the cementodentinal junction.
Table 1: Showing the average distance of gap in the cementodentinal junction

\begin{tabular}{ccccc}
\hline & Cementum & AVERAGE & STDEV.P & P value \\
\hline $\begin{array}{c}\text { Deciduous } \\
\text { teeth }\end{array}$ & Cellular & 5.904733333 & 0.60771369 & 1.013 \\
$\begin{array}{c}\text { Permanent } \\
\text { teeth }\end{array}$ & Acellular & 9.434133333 & 0.566278479 & \\
\hline
\end{tabular}

\section{DISCUSSION}

The histogenesis and mechanism of attachments of the cemento-dentinal junction of permanent teeth of humans and different species were widely discussed in previous studies $^{[1,10,11]}$. while few were interested about deciduous teeth so that the purpose of this study was to observe the cemento-dentinal junction in human mandibular deciduous $2^{\text {nd }}$ molar and the mandibular permanent $1^{\text {st }}$ molar by scanning electron microscopy combined by $\mathrm{NaOH}$ maceration.

This study showed gap between acellular cementum and root dentin with average width $9.4 \mu \mathrm{m}$ in mandibular deciduous $2^{\text {nd }}$ molars by examination with the SEM, while in cellular cementum, a fibril poor gap was observed in most of the specimens with average width $5.90 \mu \mathrm{m}$. In mandibular permanent $1^{\text {st }}$ molars specimens, poor fibril groove with average width $3.46 \mu \mathrm{m}$ were detected in acellular cementum while in cellular cementum this groove was not detected. The specimens of deciduous $2^{\text {nd }}$ molar of the current study showed no signs of intermingling between intrinsic fibers of acellular cementum and dentinal fibrils at the cementodentinal junction however in cellular cementum was detected in some areas with amorphous appearance, while in mandibular permanent $1^{\text {st }}$ molar, it showed either poor fibril groove or completely absent in both the acellular and cellular cementum consecutively.

Yamamoto and Domon et al., 2000 ${ }^{[1]}$ stated that the cemento-dentinal interface in human molars contained a smaller amount of collagen fibrils and more proteoglycans with mucopolysaccharides compared to the root dentin and cementum, and that intermingling of fibers between them was not a constant feature, that comes in accordance with the present observations of mandibular permanent $1^{\text {st }}$ molar specimens.

Although the structure of the cemento-dentinal junction may vary between different teeth and between different species, the adhesive proteoglycans are considered to be responsible for this attachment mechanism of the cementodentinal junction and that fibril intermingling plays a secondary or accessory role in this attachment ${ }^{[6,12]}$. 
The fibril intermingling between the root dentin and cementum was described as point-like processes and occurred only in places at the cement-dentinal interface. No detachment of the cementodentinal junction was reported, unless the specimens were treated by $\mathrm{NaOH}-$ maceration method, and it is reported that $\mathrm{NaOH}$-maceration method does not damage collagen fibril structure and architecture $^{[9,13]}$.

Previous studies stated that the width of the healthy cemento-dentinal junction ranges between 2-4 $\mu \mathrm{m}$ in different permanent teeth, ${ }^{[112]}$ which come in agreement with the results of mandibular permanent $1^{\text {st }}$ molar with average width $3.46 \mu \mathrm{m}$.

The average width of the cemento-dentinal junction in the deciduous $2^{\text {nd }}$ molar may be relatively higher than that of permanent which may be related to the difference between the structure and chemical composition of dentin and cementum between the deciduous and permanent teeth.

Also, Sudhakar and Pratebha, 2015 ${ }^{[13]}$ stated that the cement-dentinal junction is rich in unmineralized collagen which gets easily denatured and degraded due to any physiological or pathological changes and any loss of these collagen fibers and other proteins, that may lead to increase in the width of the cement-dentinal junction and its subsequent weakening.

\section{CONCLUSION}

- Fibril intermingling plays a role in cementum to dentin attachment.

- Other methods of cementum to dentin attachment could be postulated due to the adherence of the cementum to the dentin even in zones devoid of fibril intermingling at the cemento - dentinal junction.

\section{CONFLICT OF INTERESTS}

There are no conflicts of interest.

\section{REFERENCES}

1. T. Yamamoto, T. Domon, S. Takahashi, M. N. Islam, and R. Suzuki, "The fibrous structure of the cemento-dentinal junction in human molars shown by scanning electron microscopy combined with $\mathrm{NaOH}-$ maceration.," J. Periodontal Res., vol. 35, no. 2, pp. 59-64, Apr. 2000, doi: 10.1034/j.1600-0765.2000.035002059.x.

2. W. J. Grzesik and A. S. Narayanan, "Cementum and periodontal wound healing and regeneration.," Crit. Rev. Oral Biol. Med., vol. 13, no. 6, pp. 474-484, 2002, doi: 10.1177/154411130201300605.

3. S. P. Ho, S. J. Marshall, M. I. Ryder, and G. W. Marshall, "The tooth attachment mechanism defined by structure, chemical composition and mechanical properties of collagen fibers in the periodontium," Biomaterials, vol. 28, no. 35, pp. 5238-5245, Dec. 2007, doi: 10.1016/j.biomaterials.2007.08.031.

4. A. Nanci and A. R. TenCate, "Ten Cate's oral histology : development, structure, and function," in Ten Cate's, 9th ed., 2018, pp. 193-204.

5. J. C. Park, Y. J. Um, U. W. Jung, C. S. Kim, S. H. Choi, and C. K. Kim, "Histological characteristics of newly formed cementum in surgically created one-wall intrabony defects in a canine model," J. Periodontal Implant Sci., vol. 40, no. 1, pp. 3-10, Feb. 2010, doi: 10.5051/jpis.2010.40.1.3.

6. T. Yamamoto, T. Hasegawa, T. Yamamoto, H. Hongo, and N. Amizuka, "Histology of human cementum: Its structure, function, and development," Jpn. Dent. Sci. Rev., vol. 52, no. 3, pp. 63-74, Aug. 2016, doi: $10.1016 /$ j.jdsr.2016.04.002.

7. K. Vandana and R. Haneet, "Cementoenamel junction: An insight," J. Indian Soc. Periodontol., vol. 18, no. 5, pp. 549-554, 2014, doi: 10.4103/0972-124X.142437.

8. G. S. Kumar, "Orban's oral histology and embryology," in Orban, 14th ed., 2015, Cementum pp. 116-134.

9. T. Yamamoto, T. Hasegawa, H. Hongo, and N. Amizuka, "Alternating lamellar structure in human cellular cementum and rat compact bone: Its structure and formation," J. oral Biosci., vol. 61, no. 2, p. 105114, Jun. 2019, doi: 10.1016/j.job.2019.03.006.

10. T. Yamamoto, T. Domon, S. Takahashi, N. M. Islam, R. Suzuki, and M. Wakita, "The structure of the cemento-dentinal junction in rat molars.," Ann. Anat. $=$ Anat. Anzeiger Off. organ Anat. Gesellschaft, vol. 182, no. 2, pp. 185-190, Mar. 2000, doi: 10.1016/ S0940-9602(00)80081-3.

11. S. P. Ho, R. M. Sulyanto, S. J. Marshall, and G. W. Marshall, "The cementum-dentin junction also contains glycosaminoglycans and collagen fibrils," J. Struct. Biol., vol. 151, no. 1, p. 69-78, Jul. 2005, doi: 10.1016/j.jsb.2005.05.003.

12. T. Yamamoto, T. Domon, S. Takahashi, H. Islam, F. Suzuki, and M. Wakita, "The structure and function of the cemento-dentinal junction in human teeth," J. Periodontal Res., vol. 34, no. 5, pp. 261-268, Jul. 1999, doi: 10.1111/j.1600-0765.1999.tb02252.x.

13. R. Sudhakar and B. Pratebha, "Fibrous architecture of cementodentinal junction in disease: A scanning electron microscopic study," J. Oral Maxillofac. Pathol., vol. 19, no. 3, pp. 325-329, 2015, doi: 10.4103/0973-029X.174623. 


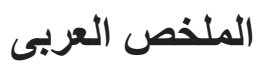

هيكل التقاطع الملاطي-العاجي في الأضر اس الثانية اللبنية للقك السفلي والأضر اس الأولى الائمة في السكان المصريين (دراسة المجهر الإلكتروني الماستح)

\author{
رنيم فاروق عبيد، رضوى طاهر الشرقاوي \\ قسم بيولوجيا الفم، جامعه المستقبل بمصر
}

مقدمة: الوصل الإسمنتي (CDJ) هو الواجهة بين الملاطو عاج الأسنان. تم وصف سبب هذا الارثباط من خلال تمازج الألياف الملاطية و العاجية أو تر اكم البروتيو غليكان اللاصق عند التقاطع الملاط العقدي. تم تصنيف الأسمنت إلى ثلاثنة

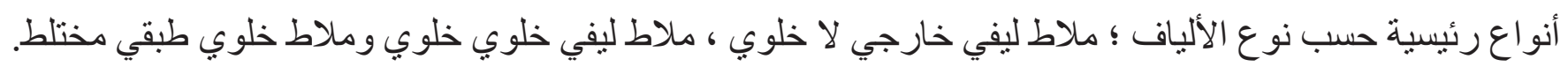

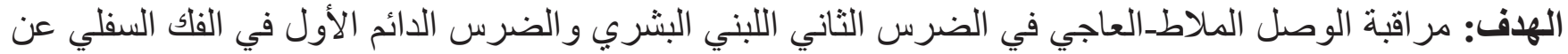

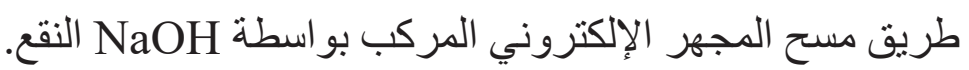

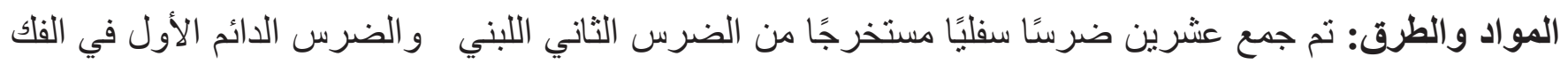

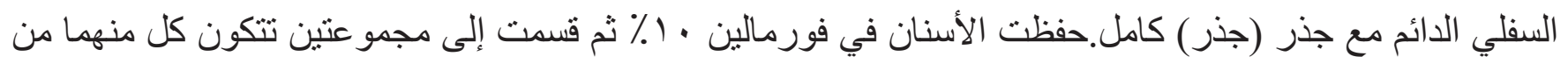

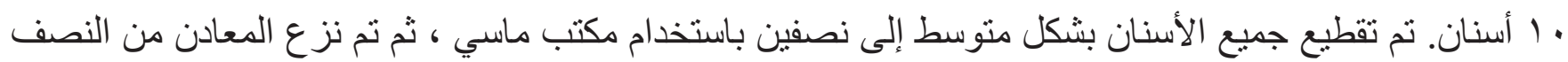

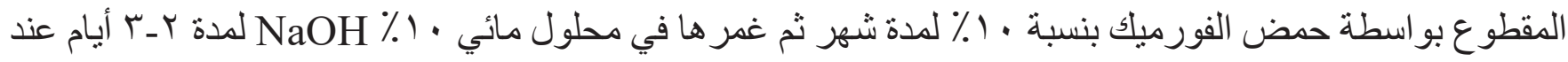
درجة حر ارة الغرفة وشطفها في ماء مقطر طو ال الليل ( ع باعة ساعة). النتائج: أظهر الملاط اللاخلوي في الأضر اس الثانية اللبنية للفك السفلي فجوة مع فصل كامل فلئل ، بينما في الملاط الخلوي هنالك فجوة ليفية ضعيفة وتداخل ليفي بين الألياف الجو هرية للملاط الخلوي و ألياف جذر العاج. لم يتم ملاحظة الفجوة

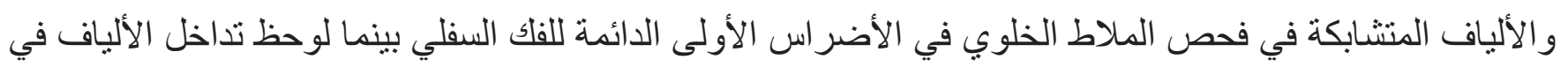
الملاط اللاخلوي. الخلاصة: يلعب تداخل الألياف دورًا في ارتباط الملاط بالعاج 